\title{
The Inhumane Treatment of People in Jail Centers: Rethinking the Duty to Protect the Health and Dignity of Prisoners in Ghana.
}

\author{
Felix Nana Kofi Ofori \\ Brunel University, Uxbridge, London.
}

\section{Abstract}

While prisoners' right to health care is recognized and protected under international human rights instruments and domestic constitution, it is also the case that majority of prisoners in Ghana, are subject to abusive treatment, inhuman conditions of living, and often denied basic access to medical treatment. This article argues, that read in light of international human rights instruments, WHO guidelines as well as the African Charter, the government, Judiciary and prison authorities in Ghana, owe it as an obligation to protect and respect the dignity of prisoners, including access to hygienic and humane living conditions.

Keywords: Prisoners' rights, access to health care, dignity, poor, sanitation, judiciary

DOI: $10.7176 / \mathrm{JLPG} / 94-21$

Publication date: February $29^{\text {th }} 2020$

Acknowledgment: I like to acknowledge Miss Lara Barbara Ofori, for reading and commenting on the draft of this article. However, all errors and limitations remain the sole responsibility of the author.

\section{Introduction}

Recent investigations conducted by a Ghanaian Journalist, Ibrahim Oppong Kwarteng ${ }^{1}$, revealed brazen and repeated violations of prisoners' rights to health care across the country. For example, the investigations showed that many pregnant women including nursing- mothers and their babies, are kept in prisons/cells without access to pre-natal or anti-natal facilities, thus damaging their health and wellbeing, in violation of human rights, World Health Organization standards and regulations. In addition, the investigations manifested that prisoners are poorly fed, lack access to basic sanitation facilities, live in over-crowded cells, contract contagious diseases, and above all, are treated inhumanely by the prisoner authorities, which further undermine their human dignity. Similarly, Kwarteng's investigations about the poor living conditions of Ghanaian prisoners resonated with the adverse reports by Juan Mendez ${ }^{2}$, UN Special Rapporteur for Torture, who visited major prison centres in Ghana, few years ago.

The duty to protect prisoners' health is a protected obligation under several human rights treaties, with the UN's Universal Declaration of Human Rights (UDHR) $)^{3}(1948)$ as the cornerstone of all contemporary human rights obligations. Article 25 of the UDHR, enjoins all States parties to the Convention, to institute quality medical establishments, to promote the wellbeing of prisoners as dignified human beings without discrimination. This obligation equally falls on Ghana as a state party to the UDHR, to establish adequate medical facilities within prison centers, to treat basic illnesses and complicated diseases-HIV/AIDS, Tuberculosis, Hepatitiswhich threaten the lives of prisoners.

The question being investigated in this article is: how do international human rights instruments and WHO principles interact with chapter 5 provisions of Ghana's 1992 Constitution to protect prisoners' right to health care in their solitary confinements?

To answer the above question, this article, which is based on doctrinal research, is in four parts. Part 1, draws on international human rights instruments - Universal Declaration of Human Rights (UDHR), International Covenant on Economic, Social, Cultural Rights (ICESCR), International Covenant on Political and Civil Rights (ICCPR), UN General Comments, UN Resolutions and World Health Organization (WHO) principles- in making the case, that regardless of their convicted status as prisoners, prisoners retain their inherent dignity as human beings. Thus, the government of Ghana including prisoner authorities, police service and the judiciary, have an obligation to protect the health and dignity of all prisoners without discrimination. Part 2, examines the African Human Rights and Peoples' Freedom (African Charter) in light of the African Commission's roles as well as the evolving jurisprudence of the African Court, in suggesting, that African States including Ghana, are obliged to protect the dignity and health needs of prisoners. Part 3, relies on the principles of the International Commission of Jurists to state that Ghana's judiciary has an obligation to protect prisoners against abuses, by interpreting chapter 5 provisions of the 1992 Constitution to promote their health needs. Part 4 argues that the government of Ghana should implement policies geared toward training, rehabilitating and developing prisoners' practical skill-sets, in order, to transform them into capable employees, who will participate in the socio-economic ventures of the Ghanaian economy, when they are released.

\section{The Right of Prisoners to Health care under International Law and Human Rights Treaties}

States' obligation to protect the rights of prisoners to attain the highest standard of health care, is enshrined in several international law and human rights instruments. These include: UN Treaties, Human Rights Instruments, UN Resolutions, WHO's Guidelines and Principles, the African Charter and its jurisprudence as well as aspects of the 1992 Constitution of Ghana.

Under the International Covenant of Economic, Social and Cultural Rights (ICESCR), prisoners' right is stated ${ }^{45}$, and this right applies universally to all those deprived of their liberty and kept in solitary confinements, without discrimination. ${ }^{6}$ Equally, this right finds expression in the International Covenant on Civil and Political Rights (ICCPR) regime. ${ }^{7}$ Being one of the first signatory states

\footnotetext{
${ }^{1}$ Ibrahim Oppong Kwarteng is an investigative Journalist and founder of Oppong Prisoner Foundation. He advocates the rights of prisoners by working with state and private organization to promote welfare and the release of those wrongly jailed.

${ }^{2}$ UN, Human Rights Council (2014), Report, Special Rapporteur on Inhuman and degrading treatment or Punishment (Juan E. Mendez) A/HRC/25/60Add.1,5 March

${ }^{3}$ UN Universal Declaration of Human Rights (UDHR) (1948)
}

\footnotetext{
${ }^{6}$ International Covenant on Economic, Social and Cultural Rights (ICESCR) (1966) Article 12 (2) (a-d)

${ }^{7}$ International Covenant on Civil and Political Rights (ICCPR) (1966) Article 6) (1)
} 
in the Sub-region of Africa to ratify the ICESCR and ICCPR, Ghana is obliged to adopt practical measures, which translate into providing health and medical facilities, to cater for the health needs of prisoners without discrimination. In its 2013 observation on Persons with disability right to health, the United Nations Human Rights Committee, stated that, "improper health conditions in prisons and detention centers can have a consequence of creating further disabilities to already existing ones. Proper identification should be given to these conditions and adopt preventive measures to avoid progression of an existing disability or further disabilities in the prisoner." The UN Commission's observation reveals two failings of Ghana Governments (past and Present governments) with respect to prisoners' health. On one hand, majority of prisoners in the country, have limited access to basic health care and related support; and, on the other hand, those prisoners who had minor health problems prior to entering jail centres end up becoming poorer or develop complicated medical conditions. This abnegation of responsibility by the Ghanaian authorities, to provide for the health needs of the inmates not only breaches their fundamental human rights, but also violates international obligations and UN standards.

States' obligation to provide adequate access to health facilities within solitary confinements is implied in the right to life; ${ }^{2}$ as well as recognized in the mandates of international law, especially under the ICCPR. ${ }^{3}$ Both the right to life and right to humane treatment oblige states, which have signed and ratified the ICCPR Convention to protect the health of all prisoners in custody. This obligation requires of government institutions and agencies to adopt proactive medical programmes to advance the health needs of all prisoners. However, reports by Kwarteng and the UN Rapporteur, revealed that majority of Ghanaian prisoners are developing complicated medical conditions at prison centers in the country without substantive therapeutic remedies to treat them.

The concept of the right to "the highest attainable standard of health" emanated from article 25(1) of the UDHR", emphasising that medical care for prisoners, constitutes a primary responsibility which governments must respect and protect, always. The phrase "lack of livelihood beyond his control" in Article 25 (1) of the UDHR, is construed to suggest that, by their confinement, prisoners have no liberty or freedom to access hospitals, clinics or other health facilities to receive medical treatment in respect of their wellbeing. Nan Miller (1995) also argues in respect of Article 5 of the UDHR, explaining that states parties' failure to ensure proper and efficient healthcare delivery for prisoners constitute torture and inhumane treatment.

Thus, the duty to protect prisoners' healthcare is not only enshrined in the above selected international law and human rights treaties, but they are also stated in the principles of the WHO, as explored in the subsequent sections.

WHO's Principles Guaranteeing Prisoners' Right to Healthcare

Principle 1 of the Medical Ethics, which was initiated by the World Health Organization (WHO) and endorsed by the UN Resolution $37 / 194^{5}$, states that UN states parties including physicians, shall accord to prisoners the same professional care given to the ordinary patient outside the prison environment. This resolution obliges physicians and allied health personnel who operate in prison centres, to offer prisoners the best health care, commensurate with their dignity as human beings without discrimination on grounds of status or position. Furthermore, this principle seeks to stem the indifference and discriminatory attitude with which most physicians, attend to the medical needs of prisoners 'based on their poor status in society ${ }^{6}$ By extension, principle 2 of the Medical Ethics instructs medical personnel and allied health workers not to use their expertise and resources to engage in any collaborative activities with governments, prison authorities, government agency or private organisations, to participate in covet/overt plans designed to inflict torture or any degrading treatment against prisoners or people in custody. ${ }^{7}$

The UN General Assembly (UNGA) adopted Resolution 37/194 in 1982 to support WHO in promoting the health and dignity of prisoners; however, persistent violations of prisoners' right to health care still exists in many developing countries, including Ghana.

Similarly, states parties to the WHO Constitution, have a duty to protect the dignity of prisoners as human beings in recognition of the principle, that "all prisoners shall be treated with their due inherent dignity and value as human beings." ${ }^{8}$ Paragraph 5 of UN Resolution 45/111 alludes to the $\mathrm{UDHR}^{9}, \mathrm{ICCPR}^{10}$ and $\mathrm{ICESCR}^{11}$ (which constitute the international bills of human rights), explaining that prisoners have the liberty to enjoy all those benefits set out by the WHO because their prison status does bar them. This principle also affirms the UN Special rapporteur to Africa, Juana Mendez's report, that prevailing conditions in Ghana's prisons contravene international obligations and undermine prisoners' right to adequate healthcare.

Prisoners' Right to receive Professional Medical Advice/care

According to WHO's guidelines, prisoners have equal right as patients in hospitals or other medical centres ${ }^{12}$ to receive treatment without discrimination. Jiri Toman (1984) argued that prisoners' solitary confinement is not as a basis to deny them access to professional medical advice/consultation. Beyond the UDHR and WHO's obligations, the United Nations General Assembly (UNGA)

${ }^{1}$ UN Human Rights: Office of the High Commissioner- Observations on the Standard Minimum Rules for the Treatment of Prisoners, CRPD/SMR, 20 November 2013, paragraph 9.

${ }^{2}$ Article 6 (1) ICCPR (1966): Every human being has the inherent right to life. No one shall be arbitrarily deprived of his life.

${ }^{3}$ Article 10 (1) (2) (a) ICCPR (1966)

${ }^{4}$ Article 25 (1) UDHR states that: "Everyone has the right to standard of living adequate for health and well-being, of himself and his family, including food, clothing housing, and medical care and necessary social services, and the right to security in the event of unemployment, sickness and disability, widowhood, old age, or lack of livelihood in circumstances beyond his control. ${ }^{5}$ Principles of Medical Ethics: Relevant to the role of Health Personnel, Particularly Physicians, in the protection of Prisoners and Detainees Against Torture and Other Cruel, Inhuman, or Degrading Treatment or Punishment- adopted by the United Nations General Assembly, Resolution 34/194, December 18, 1982

${ }^{6}$ World Health Organization, Moscow Declaration, 'Prison as part of Public Health' October, 24, 2003

${ }^{7}$ Principles of Medical Ethics: UN General Resolutions 34/194, December 18, 1982,

${ }^{8}$ Basic Principles for the Treatment of Prisoners: adopted and proclaimed by the General Assembly Resolution 45/111 of 14 December 1990

${ }^{9}$ United Nations Declaration of Human Rights (UDHR) (1948)

${ }^{10}$ International Covenant on Civil and Political Rights (ICCPR) (1966)

${ }^{11}$ International Covenant on Economic, Social and Cultural Rights (ICESCR) (1966)

${ }^{12}$ WHO Guidelines on HIV Infection and AIDS in Prison, Geneva, March 1993 
has endorsed rules requiring members states to implement measures as well as provide facilities to protect the medical and health needs of prisoners in their respective jurisdictions. For example, in 1971, the UNGA proclaimed that the Standard Minimum Rules "shall be effectively implemented in the administration of all penal and correctional institutions and that favourable consideration shall be given to their implementation in national legislations." Without doubt, Ghana has a responsibility under the Standard Minimum Rules, to promote, protect and resect the health needs of all prisoners in her country as well as ensuring that adequate health personnel and facilities are readily provided at all prison centers.

Another example of WHO's guideline was in 1973, when the UNGA recognized the commitment to protect prisoners' right to professional medical care, and stated in a resolution that: "member states should make all possible efforts to implement the Standard Minimum Rules for the treatment of offenders in the administration of penal and correctional institutions, by framing those rules into national legislations."2 Universally, the recognition of the Standard Minimum Rules has not as yet been achieved; however, there is substantial implementation of those rules by most UN member states. The substantial implementation of those rules by member states implies that the 'Standard Minimum Rules' are emerging as part of customary international law. Thus, Ghana owes it as an international obligation to accord dignified health care to all prisoners without compromise.

Recognizing the crucial role played by medical professionals towards prisoners' health care, the international community together with the WHO, outlined some rules to guide health care providers. For example, at the first Conference of International Council of Prison Medical Services, held in 1978, at Dijon, the medical professionals' affirmed their allegiance to promote and protect the health and dignity of all prisoners without discrimination. ${ }^{3}$ Among other things, the Oath of Athens states that medical professionals are obliged to display the highest form of professional integrity to give prisoners holistic medical treatment in accordance with due diligence and respect without condoning or conniving with prison authorities to compromise their health care. ${ }^{4}$ Regardless of criticisms against the Oath of Athens in the course of health delivery, majority of medical professionals, seek to provide quality health care to prisoners in respect of WHO guidelines, UN Regulations and Human rights provisions. Therefore, it is required and expected, that the health personnel assigned to work in various cells and prison centers of Ghana, would endeavour to show professionalism in caring for the inmates.

Further to providing medical treatment for prisoners, health professionals also have a duty not to engage in any physical action or adopt emotional strategies, on their own volition or in concert with government security agencies, to inflict any harm that degrades the dignity of prisoners. Principle 2 of the Medical Ethics, once more states that, "It is an offence for health personnel, particularly Physicians, to engage, actively or passively, in acts, which constitute participation, complicity in, incitements to, or attempts to commit torture or other cruel, inhuman, or degrading treatment or punishment". 5 This principle reflects the UN's commitment to protect prisoners against inhumane and atrocious practices, as occurred in some developed states but much more pronounced in developing states, including Ghana. Significantly, Principle 2 seeks to impute criminal liability to physicians, nurses ${ }^{6}$ and other health professionals, who may engage in any of the acts referred to, in the above statement.

\section{The Right to Preventive Health care}

Woodall, et al (2014:125) argue that, "... improving the health of individuals confined within prisons can positively affect the health of prisoners' immediate family and relatives". This view resonates with the idea of preventive health care, which is a duty protected by $\mathrm{WHO},{ }^{7} \mathrm{UN}^{8}$ and other human rights organizations. ${ }^{9}$ Simply, the wisdom of providing preventive care in prison centers, underlines the health strategy of stemming the spread of contagious diseases from prisoners to the extended community. Thus, under WHO mandate ${ }^{10}$, member states of the UN have an obligation to adopt preventive measures to protect prison inmates and their families against contracting deadly diseases- HIV/AIDS, Tuberculosis, Hepatitis B and drug abuse. Ghana has an obligation to protect the health of its prisoners so as to stymie the spread of deadly disease in the country.

\section{The Right to Adequate Living space}

The provision of adequate living spaces for prisoners is a duty for state parties including prisons authorities to implement in accordance with the Geneva Convention ${ }^{11}$ as well as Human Rights principles. ${ }^{12}$

${ }^{1}$ G.A. Res. 2858 U.N. GAOR, $26^{\text {th }}$ Sess., Supp, No. 29 at U.N. Doc A/8588 (1971)

${ }^{2}$ G.A. Res. 3144 , U.N. GAOR, $28^{\text {th }}$ Sess., Supp. No. 30 at 85, U.N. Doc A/9425 91973)

${ }^{3}$ The International Council of Prison Medical Services, Recognition of the rights of incarcerated individuals, Dijon, November, 1978

${ }^{4}$ The International Council of Prison Medical Services, Principle 10, Athens, September 1979

${ }^{5}$ The International Council of Nurses, Position Statement, ibid

${ }^{6}$ International Council of Nurses, Position Statement, The Nurses' Role in the Care of Prisoners and Detainees, 1998

${ }^{7}$ WHO, Constitution of WHO: Principles, Basic Document, Forty-fifth, edition, Supplement, October 2006

${ }^{8}$ United Nations Standard Minimum Rules for the Treatment of Prisoners, (1955) adopted, August 30, First UN Conference on Prevention of Crime and Treatment of Offenders, U.N. A/CONF/611

${ }^{9}$ Human Rights and Prisons (2005) A Pocket of International Human Rights Standards for Prison Officials, Geneva/New York 10 "All prisoners have the right to receive health care, including preventive measures, equivalent to that available in the community without discrimination... WHO (1993)

${ }^{11}$ Geneva Convention Related to the Protection of Civilian Persons, (1949), adopted, 12 August 1949 by Resolution ....

Article 37 of the Geneva Convention, states that 'protected persons who are confined pending proceedings or serving a sentence involving loss of liberty, shall be humanely treated. Article 38 of the Geneva Convention also states that 'Civilian persons detained in prison/cell shall be protected against of measures- designed to undermine their dignity as human beings

${ }^{12}$ Human Rights and Prisons, note 27, ibid: section III states that 'All persons deprived of their liberty, shall have the to an adequate living standard of living, including adequate food, drinking water, accommodation, clothing and bedding.' 
First, drawing on Article $25^{1}$ of the UDHR, detaining authorities, prison services and public or private institutions, engaged with the management of prisons, have a duty to provide adequate and quality good food at regular intervals, and on daily basis to nourish the physiological and the emotional wellbeing of prisoners. This obligation also requires that inmates have their privacy respected, so that they can comfortably discuss issues with their families and friends during moments of visitation. ${ }^{2}$ However, as evidenced by the UN Rapporteur ${ }^{3}$ and Kwarteng's reports ${ }^{4}$, majority of Ghanaian prisoners live in jails and cells, infested with mosquitoes, cockroaches, poor sanitation and unhygienic environment.

Second, the other limb of the right to adequate living space in respect of prisoners' right is the duty to accommodate them humanely. Article $16^{5}$ of the Convention against Torture, requires of States and their respective prison authorities, to organize decent sleeping accommodations with proper ventilation, lightening, toilets and bathroom facilities, to ensure that, their physical appearances and personalities reflect the dignity of humans. In addition, each prisoner should live in a separate room or bed where a dormitory system of housing is provided, to reflect the privacy of the inmates. Furthermore, climatic conditions and adequate floor space need careful planning, in allocating sleeping accommodations for the prisoners. Unfortunately, Ghana's prison centers are overcrowded, culminating in rough sleeping among the inmates thereby giving rise to increased communicable diseases as well as respiratory problems. $^{6}$

Third, adequate clothing and bedding are yet another of Prisoners' rights to which state parties must adhered. Article 11 (1) ${ }^{7}$ of the ICESCR, enjoins states parties and prison authorities to provide appropriate clothing to the inmates where they are not required to wear their own clothes. This duty also obliges the prison authorities to provide suitable storage and laundry facilities to ensure that prisoners maintain decent and hygienic appearance conforming to their human status. Rule 17(1) (2) (3) of the Standard Minimum ${ }^{8}$ affirms this obligation as well.

As mentioned by the UN Rapporteur's report ${ }^{9}$ and affirmed in Kwarteng's ${ }^{10}$ investigations above, Ghana has reneged on its international law obligations in this respect. For example, In General Comment No. $3,{ }^{11}$ the ECOSOC Committee explained in detailed the obligations owed by states parties to the Covenant, making the case that flexibility to implementing the Covenant provisions, do not exonerate states from abdicating on their commitments to protect their peoples' rights especially the vulnerable. Paragraph 9 of General Comment No.3 provides that "... the concept "progressive realization" constitutes a recognition of the fact that realization of all economic and social rights will generally not be able to achieve in a short period... Nevertheless, the fact that realization over time, or in other words progressively, as for seen under the Covenant should not be misinterpreted as depriving the obligation of all meaningful content. This is a flexibility." 12 By the interpretation of Paragraph 9 of the General Comment No. 3, Ghana is obliged under the ICESCR Covenant to adopt "progressive measures" and "positive steps" to eliminate all cruel and degrading practices from all prison premises in the country. This is because "taking positive steps" entails implementing concrete, deliberate and targeted actions to address and improve the social and economic wellbeing of their peoples, of which prisoners form a legitimate part.

Similarly, to ensure that those deprived of liberty through incarceration enjoy the substantive benefits of ICESCR, General Comment No.3, stated that a period of one decade after signing or ratification of the Covenant, is enough to implement practical programmes earmarked to improving the social and economic wellbeing of the peoples. ${ }^{13}$ Ghana signed and ratified the ICESCR ${ }^{14}$ in the same year of its inception; however, nearly twenty years as at the time of writing this article, the standard of health among its prisoner population is appalling and dehumanizing. Furthermore, General Comment No.3 rejects the arguments of economics as a barrier to protecting prisoners' rights under the ICESCR. At paragraph 12 of General Comment No.3, the Commission state that, "In

\footnotetext{
${ }^{1}$ Article 25 of UDHR, states that 'Everyone has the right to standard of living adequate for his health and wellbeing ... including food, clothing, housing, medical care and social services, and the right to security in the event of ... lack of livelihood in circumstances beyond his control'.

${ }^{2}$ Article 11 of ICESCR, states that 'the States Parties to the present Covenant recognize the right of everyone to an adequate standard of living for himself and his family, including adequate food, clothing and housing, and to the continuous improvement of living conditions.

${ }^{3} \mathrm{UN}, \mathrm{HRC}$, see note 3 , ibid.

${ }^{4}$ Ibrahim Oppong Kwarteng, see note 1, ibid.

${ }^{5}$ Article 16, of the Convention against Torture and other Cruel, Inhuman or Degrading Treatment, states, 'Each state shall undertake to prevent in any territory under its jurisdiction other acts of cruel, inhuman or degrading treatment or punishment which do not amount to torture ... when such acts are committed by or at the instigation of or with the consent of or acquiescence of a public official or other person acting in an official capacity..

${ }^{6}$ UN, HRC, Special Rapporteur on Torture, (2014), see note 3

${ }^{7}$ Article 11 (1) of the ICESCR, 'provides for the right to clothing as a component of the right of everyone to an adequate standard of living

${ }^{8}$ Rule 17 (1) 'Every Prisoner who is not allowed to wear his own clothing shall be provided with an outfit which of clothing suitable to for the climate and adequate to keep him in good health. Such clothing shall in no manner be degrading or humiliating. Rule 17 (2) 'All clothing shall be clean, and kept in proper condition. Underclothing shall be changed and washed as often as necessary for the maintenance of hygiene. Rule 17 (3) 'In exceptional circumstances, whenever a prisoner is removed outside the institution for an authorized purpose, he shall be allowed to wear his own clothing or other inconspicuous clothing. ${ }^{9}$ UN, HRC Rapporteur, see note 3, ibid

${ }^{10}$ Ibrahim Oppong Kwarteng, see note 1, ibid.

${ }^{11}$ UN General Comment No. 3: The Nature of States Parties obligation (art. 2, 1 para.1) (1990), adopted by the Committee on Economic, Social and Cultural Rights at the Fifth Session, E/1991/23,14 December 1990)

${ }^{12}$ Paragraph 9, UN, General Comment No. 3, see note 41, ibid

${ }^{13}$ Paragraph 10 of the UN General Comment No.3, see note 41, ibid

${ }^{14}$ UN Human Rights: Office of the Human Rights Commissioner, UN Treaty Data Body Database,

Ghana signed and ratified the UN ICESCR on 7 September 2000 respectively.
} 
times of severe resources constraints whether caused by a process of adjustment of economic recession or by other factors the vulnerable members of society can and indeed must be protected by the adoption of low-cost target programme". ${ }^{1}$

Rich in copious mineral resources- Gold, Timber, Bauxite, Cocoa and oil, and with a population size of under thirty (30) million people, one wonders why Ghana struggles to implement effective health care system to protect the wellbeing of its prisoners. In recent years, the World Bank has rated Ghana as one of the fastest growing economies in the sub region of Africa. ${ }^{2}$ This implies that, protecting the health needs of its prison population should be fairly easy. However, Craig Martin (2019) indicates the difference between inability and unwillingness. On one hand, "inability" simply means lacking the power or resources to perform a task, carry out a duty or obligation; and on the other hand, "unwillingness" implies disinclined or reluctant to do something. Viewed in this light, the governments of Ghana and the affiliated authorities, seemed unwilling to promote the health of prisoners. Furthermore, Vusi Gumede (2016) explains that a visionary political leadership is a requirement for a nation's development. By implication, then, Ghana needs a visionary leader to promote the socioeconomic prospects of the country, so as, to improve the health needs of prisoners.

\section{The Protection of Prisoners' Rights under the African Commission}

For prisoners' health to be protected with dignity, an independent and effective system of judicial enforcement is required to construe the provisions of the African Human Rights and Peoples' Freedoms (African Charter), practically. For this reason, the heads of States and governments of the Organization of the African Union (OAU) promulgated the African Charter ${ }^{3}$, to institutionalize human rights, primarily those of prisoners in compliance with international human rights norms, laws and regulations.

Article 5 of the African Charter frowns upon maltreating detained persons, by either governments or prison authorities. ${ }^{4}$ Although provisions of Article 5 of the African Charter do not directly allude to prisoners, yet, there is an implied duty on state parties and their respective prison authorities, to ensure that prisoners are not subject to degrading or inhumane treatment because their confined status.

Under the African Charter, a Commission on Human and Peoples' Rights ("The Commission") 5 , was established to promote and guide state parties, including prison authorities, to abide by human rights tenets to safeguard prisoners' rights. In addition, the provisions of Article 3 state that members of the Commission must possess attributes, such as, a high sense of integrity, competency in human rights law and independent-mindedness. These attributes are required in the commissioners, so as, to defend the dignity of the peoples, always. ${ }^{6}$ By extension, Article 31(2) states that members of the Commission must "act in their personal capacity..."7 The phrase "personal capacity" legally means that the elected/appointed Commissioner must be someone with a disposition to respect human rights law, moral values and the bravery to pronounce judgments against government and public agencies without fear or favour. Furthermore, the phrase refers to an individual's commitment to advance the cause of humanity without seeking any personal or expedient gains. Thus, it is crucial that the Commissioner(s) seek to exercise their role in pursuance of human dignity and wellbeing rather personal gains.

Article 45 of the African Charter $^{8}$ further outlines the Commission/Commissioners' functions to include but not limited to the following:

(b) Formulate and lay down principles and rules aimed at solving legal problems relating to human and peoples' rights and fundamental freedoms upon which African Governments may base their legislations ${ }^{9}$

(c) Cooperate with other African and International Institutions concerned with the promotion and protection of human and Peoples rights ${ }^{10}$

2 Ensure the protection of human and peoples' rights under conditions laid down by the Charter ${ }^{11}$

3 Interpret all the provisions of the Charter at the request of a State Party, an Institution of the AU or an African institution organized by the $\mathrm{AU}^{12}$

4 Perform any other task which may be entrusted to it by the Assembly of the Heads of States and Governments. ${ }^{13}$

${ }^{1}$ Paragraph 12 of the UN, General Comment No.3, see note 41, ibid

${ }^{2}$ The World Bank in Ghana: An Overview of the Economy (2018)

${ }^{3}$ The African Charter on Human and Peoples' Rights ("The Charter") was signed July 17, 1985 and entered into force, October 21,1986 respectively

${ }^{4}$ Article 5 of the African Charter, see note 47 ibid: "every individual shall have the right to the respect of the dignity inherent in a human being and to the recognition of his legal status. All forms of exploitation and degradation of a man particularly slavery, slave trade, torture, cruel, inhuman or degrading punishment and treatment shall be prohibited.

${ }^{5}$ Article 30 of the African Charter, ibid: "An African Commission on Human and Peoples' Rights, ("The Commission") shall be established within the Organization of African Union to promote Human and Peoples' Rights and ensure their protection in Africa

${ }^{6}$ Article 31 of the African Charter, ibid. "The Commission shall consist of eleven members chosen from amongst African personalities of the highest reputation, known for their high morality, integrity, impartiality and competence in matters of human and peoples' rights; particular consideration being given to persons having legal experience.

${ }^{7}$ Article 31(2) of the African Charter, ibid

${ }^{8}$ Article 45 (a) states that: "the Commission shall promote the human and Peoples' rights by undertaking the functions:

(a) To collect documents, undertake studies and researches on African problems in fields of human and peoples' right, organize Seminars, Symposia and Conferences, disseminate information, encourage National and Local Institutions concerned with human and peoples' rights, and should the case arise, give its views or make recommendations to Governments.

${ }^{9}$ Article 45(b), ibid

${ }^{10}$ Article 45 (c) ibid

${ }^{11}$ Article 45 (2) ibid

${ }^{12}$ Article 45 (3) ibid

${ }^{13}$ Article 45 (4) ibid 
It is worth noting, that the Commission's judgments and recommendations have no legal binding effect on state parties to Charter, therefore, most states tend to ignore them. This practice has been severely criticised by Evans and Murray (2002) as undermining the legitimacy of the Commission as well as eroding the inherent dignity of the most vulnerable in society, especially the prisoners.

A judicial forum (Court/Tribunal) serves as a platform on which one vies for a legal right or entitlement. Article 49 of the African Charter states that "A state party with good reason to believe that another state party to the Charter has violated provision of the Charter, may draw the Commission's attention to it by communication". ${ }^{1}$ This also means that the Commission may not entertain any communication or complaint which is superfluous or of a frivolous nature. Furthermore, Article 50 of the African Charter requires of state parties to exhaust all internal mechanisms of disputes resolution in their domestic jurisdictions before lodging complaint to the Commission for determination. ${ }^{2}$ The significance of this legal requirement is to strengthen the powers of the domestic judicial institutions to protect their citizens against human rights breaches; and also to ensure "the protection of human rights by the African Charter as subsidiary to National systems". ${ }^{3}$ Thus, in comity with regional human rights courts, exhausting of domestic remedies is a recognized practice in international law.

The Commission's jurisprudence, which is evolving in the face of logistical challenges, are provided here to emphasize the point, that with adequate resources human and prisoners' rights, can be effectively protected to advance domestic policies relating human development across the region. The following are selected cases in that respect.

First, Promoting Justice for Women and Children (PROJUST) v. Democratic Republic of Congo ${ }^{4}$, concerned the arrest, torture and detention of six Congolese women; second, Dr Farouk Mohamed Ibrahim (represented by REDRESS) v. Sudan ${ }^{5}$, related the arrest, detention and molestation of an associate professor and his department staff at the University of Khartoum. In both cases, the Commission held that the complainants failed to fully exhaust domestic remedies in their jurisdictions, therefore, it dismissed those claims in respect of Article 50 of the African Charter.

Conversely, Spilg and Mack \& DISTHWANELO v. Botswana ${ }^{6}$ alleged that Bernard Kobedi killed a Botswana Police sergeant and was sentenced to death; whereas, Abdel Hadi, Ali Raid \& Others v. Republic of Sudan ${ }^{7}$, involved the arrest and beating of some Sudanese nationals by the Police, for inciting public unrest. Passing judgment, the Commission held in both cases, that the Botswana Government had breached Charter provisions by passing death sentence against Kobdei; and, also found the Sudanese authorities liable for inhumanely treating the complainants.

In light of the judgments above, it is learned that the Commission is resolved to advance the cause of prisoners as espoused in the Lome Resolution, ${ }^{8}$ urging state parties to adopt programmes and legislative provisions to protect prisoners' rights. Furthermore, as a policy of urgency, the Ghanaian authorities should endeavour to institute catering facilities within all police cells and jail centers, to provide nutritious meals at regular intervals, to promote the health and physiological needs of all prisoners without discrimination. Moreover, the subsequent establishment of the African Human Rights Court (The African Court), is a testament of the Union's further determination to improve the human rights of African, especially prisoners

\section{The African Human Rights Court and the Protection of Prisoners Rights}

The effort to promote the peoples' dignity and human rights on the Continent of Africa, led the heads of States and Governments, to

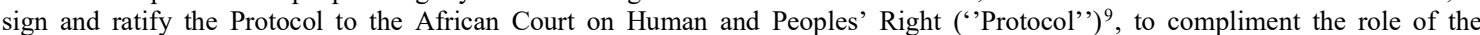
Commission in adjudicating human rights cases. Originally, the African Court operated from November 2006 in Addis Ababa in Ethiopia but moved to its present and permanent seat in Arusha, Tanzania on August 2007. ${ }^{10}$ Oule, Rwentlow and Curling (2019) proposed, that the African Court was imbued with special and extended jurisdiction to receive and interpret provisions of the Charter, cases relating human rights violations, as well as resolve disputes concerning application of the Charter and any other relevant human rights treaty ratified by the states concerned. ${ }^{11}$ It must be noted here that the African Court's decisions, unlike the Commission, are binding upon all state parties, AU organs and institution including private individuals, thus, states are duty bound to comply with them.

In contrast with the Commission, the African Court appears more human rights-centred because of its special mandate to receive, investigate and adjudicate cases from both private individuals and NGOs. ${ }^{12}$ This implies that NGOs with observer status and private

\footnotetext{
${ }^{1}$ Article 49, ibid

${ }^{2}$ Article 50, ibid

${ }^{3}$ European Convention for the Protection of Human Rights and Fundamental Freedoms (as amended) 4 November 1950), ETS5, Article 35; see also: American Convention on Human Rights, 1144 UNTS 123, Article46(1) (a); African Charter Article $56(5)$

${ }^{4}$ Promoting Justice for Women and Children (PROJUST) v. Democratic Republic of the Congo, February 2012, ACHPR, 278/03,1 ${ }^{\text {th }}$ Extra-ordinary Session

${ }^{5}$ Dr Farouk Mohamed Ibrahim (Represented by REDRESS) v. Sudan, February 2013, ACHPR, 386/2010, $13^{\text {th }}$ Extra -ordinary Session

${ }^{6}$ Spilg and Mack \& DISTSHWANELO v. Botswana, December 2011, 277/03, $10^{\text {th }}$ Extra-ordinary Session

${ }^{7}$ Abdel Hadi, Ali Radi \& Others v. Republic of Sudan, November 2013, ACHPR, 368/09, $54^{\text {th }}$ Ordinary Session

${ }^{8}$ The African Commission on Human and Peoples' Rights: $19^{\text {th }}$ Resolution on Prisons in Africa, 17 $7^{\text {th }}$ Ordinary Session, 13-22 March 1995, Lome, Togo

${ }^{9}$ Protocol to the African Charter on Human and Peoples' Rights on the Establishment of an African Court on Human and Peoples' Rights, June, 10, 1998, Organization of African Unity (OAU), Ouagadougou, Bourkina Faso, (hereinafter the Protocol). The Protocol entered into force on June 25, 2004 and the Court stated operation in 2006 respectively.

${ }^{10}$ Article 2 of the Protocol: "The Court shall, bearing in mind the provisions of this Protocol, compliment the protective mandate of the African Commission on Human and Peoples' Rights ("The Commission") conferred upon it by the African Charter on Human and Peoples' Rights (The Charter).

${ }^{11}$ Article 3(1) of the Protocol: "The Jurisdiction of the Court shall extend to all cases and disputes submitted to it concerning the interpretation and application of the Charter, this protocol and application of the Charter, this protocol and any other relevant human rights instruments ratified by the member state concerned

${ }^{12}$ Article 5 (1) of the Protocol: "The Court shall grant access to the Commission, including the following:
} 
individuals could litigate before the Court. Another important mandate of the African Court resides in its ability to provide advisory opinion $^{1}$ at the request of the African Union (AU). The Protocols of the African Court allow Judges to render dissenting opinions in respect of all cases before the court as a surety of maintaining judicial independence. ${ }^{2}$ The following cases are demonstrations of the Court's evolving jurisprudence to protect the human rights in Africa.

First, Tanganyika Law Society v. Tanzania ${ }^{3}$, involved a challenge brought against Tanzania for breaches of Article 7 of the Ecowas Treaty. The Court decided that Tanzania had breached the applicant's rights under ICCPR, Ecowas and African Charter rights.

Second, Konatate v. Burkina Faso 4 also concerned the closure of the applicant's newspaper business as well as his imprisonment. The African Court held the Responding State liable for breaching the principle of fair trial and freedom of speech. Similarly, in Leon Mugeresa $v$ Republic of Rwand $a^{5}$, the Court held that Rwanda had violated its obligations under the African Charter and international human rights to protect prisoners' health.

Third, concerned the case between the African Commission v. Libya ${ }^{6}$ where Saif Al-Islam Kadhafi is detained in a secret location without access to legal representation. Passing judgement, the African Court affirmed that Libya had breached its obligations under the African Charter, ICCPR including other respective International treaties.

Juxtaposing the jurisprudence of the African Commission with that of the African Court, it can be stated that both judicial systems are still evolving and imperfect, however, the emerging jurisprudence exudes some confidence among the peoples, in challenging respective government for human rights violations. This also indicates that maltreatment and abuses of prisoners' rights, as reported by the UN Special Rapporteur ${ }^{7}$ are violations of rights, challengeable under the court's jurisdiction. However, Manisuli Ssenyonjo (2018:12) opines that "the African Assembly's failure to institute sanctions to compel Libya to comply with the African Court's decision suggests non-compliance and non-enforcement which might be exploited to undermine the Commission's recommendations as well as Court's orders/judgments." Thus, states should be encouraged to respect and comply with judgments and recommendations of the Court and the Commission, in order, to promote their legitimacy and credibility regionally and domestically. This will promote the protection of human rights among vulnerable peoples- especially prisoners in Africa.

Ghana signed and ratified the Protocol to the African Court ${ }^{8}$ with a view to be compliant with her human rights obligations at the regional and domestic levels. Positioning herself as an advocate of democratic values in Africa, Ghana needs to ensure that treaties signed at the international and regional levels are translated into domestic legislations to protect the welfare of the people's social, economic and political welfare. This also includes implementing practical programmes to improve the nutritional, hygienic and sanitation conditions of all prison inmates across the country. Looschelders and Olzen (2009) proposed that the principle of good faith ${ }^{9}$ operates in municipal law to "balance out unequal sides of a bargain". This statement has peculiar significance to the relationship between Ghana government and the prisoners; because, the prisoners are in a weaker/subversive position to the authorities, as their custodial confinement curtailed them. Therefore, good faith demands, that Ghana adopts practical provisions to ensure that the prisoners have effective access to good health care, adequate nutrition as well as sanitation facilities to improve their dignity. The judicial protection of prisoners' health within the 1992 Constitution of Ghana is worth exploring.

\section{Ghana's Judiciary and the Protection of Prisoners' Rights}

The Judiciary in Ghana occupies essential realm of the country's political land scape; because, it is endowed with Constitutional powers to regulates policies of the government, and to compel states institutions to respect the peoples' human rights without fear or favour. ${ }^{10}$ In addition, the Judiciary is at liberty to use its constitutional powers, independence and impartiality ${ }^{11}$ to construe Chapter

Article 5 (ii) of the Protocol: "The State Party which has lodged a complaint to the Commission

Article 5 (c) of the Protocol: "The State Party against which the Complaint has been lodged at the Commission, and the State Party whose citizen is a victim of human rights violation or an African International Organization

Article 5 (2) of the Protocol: "A State with an interest in a case

Article 5(3) of the Protocol: "Relevant NGOs with observer status, and individuals

${ }^{1}$ Article 4 of the Protocol: "At the request of the African Union (AU), any of its organs, or any African Union Organization by $\mathrm{AU}$, the African Court may provide advisory opinion on any legal matter relating the Charter or any relevant human rights instruments except where the matter is under consideration by the Commission

Article 4(2) of the Protocol: "The Court shall give reasons for its advisory opinions and every Judge shall be entitled to give separate dissenting opinions.

${ }^{2}$ European Convention for the Protection of Human Rights and Fundamental Freedoms, see note 60

${ }^{3}$ In the consolidated matter of Tanganyika Law Society and the Legal and Human Rights Centre and Tanzania and Mtikila v. Tanzania, No. 009/2011 \& 011, Judgment, Afr. Ct. H.P.R, (June 14, 2013)

${ }^{4}$ Konatate v. Burkina Faso, No. 004/2013, Judgment, Afr. Ct. H.P.R, Doc. 5.2014

${ }^{5}$ Leon Mugeresa $v$ Republic of Rwanda, Application 012/2017 (28 September 2017)

${ }^{6}$ In African Commission v. Libya, No. 002/2013, Judgment, Afr. Comm’n, H.P. R, 97, (June 32016

${ }^{7}$ UN, Human Rights Council's Report (2014), see note 3

${ }^{8}$ List of Countries which have signed and ratified the Protocol to the African Court: Ghana signed the Protocol on 31/10/2003 and ratified it on 13/06/2006 respectively

${ }^{9}$ Vienna Convention on the Law of Treaties (1969) 1155 UNTS 331, adopted 22 May 1969, entered into force 27 January 1980; Article 31(1) "A Treaty shall be interpreted in good faith in accordance with the ordinary meaning to be given to the terms of the treaty in their context and in the light if its object and purpose

${ }^{10}$ Ghana's Constitution of 1992 with amendment through 1996, approved through a referendum, 28 April 199, and entered into force, 7 January 1993, Constitutiveproject.org;

Article 12 (2) of the 1992: "Every person In Ghana, whatever his race, place of birth, political opinion, colour, religion, creed or gender shall be entitled to the fundamental human rights and its freedoms of the individual c

${ }^{11}$ Article 42(2), The Judicial Power of the State in the judiciary gives the Supreme Court original jurisdiction to determine questions of constitutionality 
five provisions of Ghana's 1992 (amended 1996), ${ }^{1}$ in the light of international human rights instruments (ICCPR) ${ }^{2}$, (ICESCR) ${ }^{3}$ as well as the African $\mathrm{Charter}^{4}$ to protect the dignity of prisoners. This also demands, that judges draw on judicial activism, ${ }^{5}$ to interpret international human rights conventions to which Ghana is signatory in protecting the dignity of all citizens especially prisoners, ${ }^{6}$ whose rights are restricted. Suzanna Sherry (2013) states that "Judicial activism means judges' power to strike down policies, legislations or regulations by either executive or legislative branch of government, which conflicts with and undermines the progress of society." In this respect, judges of the Supreme, Appeal and High Courts of Ghana, should commute arbitrarily higher sentences into community work for minor offences, with the aim of reducing jail terms for pregnant women and other vulnerable offenders.

The International Commission of Jurist ${ }^{7}$, which recognizes the role of judicial independence to protect human rights, has formulated certain principles to help judges advance the dignity of all peoples particularly prisoners' welfare. Some of those principles ${ }^{8}$ resonate with, and are affirmed under the UNGA's Resolution ${ }^{9}$ to safeguard the sanctity of prisoners. The implication is that judges have an obligation to exercise impartiality and freedom to interpret international and domestic instruments, to ensure that prisoners kept in solitary jails centers across Ghana get the needed health care. For example, senior judges in Ghana could adopt judicial activism principles to protect those convicted of minor crimes against arbitrarily longer prison terms ${ }^{10}$

In one of his writings, Lord Bingham (2010:53) stated "it is also, however, injustice if the severity of a criminal sentence is dictated by judicial prejudice, or predilection or whim..." As Kwarteng's investigations revealed, ${ }^{11}$ most prisoners in Ghana serve long-jail terms in and across various prison centers; because of judicial prejudice or whim, which is contrary to the provisions of the 1992 Constitution. Thus, Ghanaian Judges should act as glue in holding together the judicial system and adapt provisions of the international human rights law to protect the welfare of prisoners. Furthermore, the judges should scrutinise the activities of the prosecutorial officials (police and state lawyers), to ensure that constitutional or procedural rules are not manipulated to achieve verballing ${ }^{12}$, which had contributed to high numbers of incarceration among the uneducated and poor Ghanaians.

The practice of verballing among many Ghanaian police officers is not only an affront to the principles of fair trial, but also a violation of the dignity and human rights of those prisoners who suffer injustice. Committing innocent and vulnerable people into jail/prison terms through verballing not only caused significant damage to the fabric of society, but equally result in what economists describe as 'opportunity cost' (Yuval Harari, 2018). That means that, the money, time and infrastructure, committed by the state to

\footnotetext{
${ }^{1}$ Ghana's Constitution of 1992 with Amendments through 1996, ibid

${ }^{2}$ ICCPR, see note 6

${ }^{3}$ ICESCR, see note 5

${ }^{4}$ African Charter, see note 47
}

${ }^{5}$ Judicial activism is "the view that the Supreme Court and other Judges can and should creatively (re) interpret the Constitution and the law to serve the Judge's own visions regarding the needs of society. Judicial activism believes that Judges assume a role as independent policy maker on behalf of society

${ }^{6}$ Article 15(2) states that: "The dignity of all persons shall be inviolable

${ }^{7}$ The International Commission of Jurists (ICJ) is a non-governmental Organization devoted to promoting the understanding and observance of the rule of law and the legal protection of human rights throughout the world. It is located in Geneva, Switzerland, and has 85 national sections and affiliated organizations. It enjoys consultative status in the United Nations Economic and Social Council, UNESCO, the Council Europe and the Organization of African Unity as well as relations with various bodies of the organizations of the American States.

${ }^{8}$ International Commission of Jurist, Principle 1 . The independence of the judiciary shall be guaranteed by the States and enshrined in the Constitution or the law of the country. It is the duty of government and other institutions to respect and observe the independence of the judiciary;

Principle 2. The judiciary shall decide matters before them impartially, on the basis of facts and in accordance with the law, without any restrictions, improper influences, inducements, pressures, threats and or interferences, direct or indirect, from any quarter or for any reason;

Principle 3. The judiciary shall have jurisdiction over all issues of a judicial nature and shall have exclusive authority to decide whether an issue submitted for its decision is within its competency as defined by law;

Principle 4. There shall not be any inappropriate or unwarranted interference with the judicial process, nor shall judicial decisions by the courts be subject to revision. This principle is without prejudice to judicial review or to mitigation or communication by competent authorities of sentences imposed by the judiciary, in accordance with the law;

Principle 5. Everyone shall have the right to be tried by ordinary courts or tribunals using established legal and procedures. Tribunals that do not use duly established procedures of the legal process shall not be created to displace the jurisdiction belonging to the ordinary courts or judicial tribunals

Principle 6. The principle of independence of the judiciary entitles and requires the judiciary to ensure that judicial proceedings are conducted fairly and that the rights of the parties are respected.

${ }^{9}$ Special standards on the Independence of Judges, Lawyers and Prosecutors, adopted by the Seventh United Nations Congress on the Prevention of Crime and the Treatment of Offenders held at Milan from 26 August to 6 September 1985 and endorsed by General Assembly resolution 40/32 of 29November 1985 and 40/146 of 13 December 1985

${ }^{10}$ Article 14(4) states that "Where a person arrested, restricted or detained under paragraph (a) or (b) of clause 3 of this Article is not tried within a reasonable time, then, without prejudice to any further proceedings that may be brought against him, he shall be released either unconditionally or upon reasonable conditions, including in particular, conditions reasonably necessary to ensure that he appears at a later date for trial or for proceedings to trial.

${ }^{11}$ Ibrahim Kwarteng Oppong, see note 1

${ }^{12}$ Verballing is simply fabrication of confession statements by a police officer in order to achieve conviction of innocent or uneducated suspect. With high level of corruption and uneducated masses in Ghana, verballing has become a means through which police officers achieve conviction and enrich themselves 
keep the prisoners in jail, would negatively affect the provision of socio-economic projects to promote the growth and development of Ghanaians and the country at large.

Thus, the courtroom becomes a theatre in which Judges ought to be the protagonists to defend, protect and promote prisoners' rights according to the constitutional provisions of the 1992 Constitution. Anthony Gabby (1997: 232) affirms this premise, arguing that: "Judges should address human rights issues with boldness, imagination, and creativity. Their primary duty is to make a constitution grow and blossom in order to meet the just demands and aspirations of an ever-developing society". One case in Ghana's judicial history (jurisprudence) (Ahumah Ocansey $v$ The Electoral Commission, Center for Human Rights, 2010) ${ }^{1}$, has demonstrated that sense of judicial creativity and imaginativeness required to protect the human rights of prisoners. In addition, the Ahumah case, which granted voting rights to prisoners in Ghana, at the time, uniquely sets the precedent, inviting judges in the Supreme, Appeal, High and Magistrates' Courts of Ghana, to re-think the duty to protect prisoners' rights in the context of international and constitutional instruments.

\section{Re-thinking the Duty to Protect the Dignity of Prisoners in Ghana}

The need to adopt proactive legal and rehabilitative measures to improve prisoners' wellbeing so as to re-integrate them in society is very urgent.

First, there is a moral and constitutional obligation on the part of the Ghanaian media to expose the poor, squalid, inhuman and countless abuses, which most prisoners suffer. By publishing the cruel and degrading treatment of prisoners, the people's conscience may be sensitized to engage in national discussions, debates, and possibly a change in government's policy favourable towards prisoners. For example, as revealed in Kwarteng's report ${ }^{2}$, the media could select one or two instances of prisoners' maltreatment to induce public sympathy and outcry, as a strategic ploy to pressurize the government and prison authorities to introduce immediate welfare and reform schemes.

Second, Ghana must debunk the practice of using prisons and jail centers as warehouses for bad people. The authorities should seek to transform prison centers into capacity building avenues in respect of the country's economic policy of 'Ghana beyond Aid'3. This policy would ensure that prisoners receive practical vocational, apprenticeship and formal educational instructions, coupled with rehabilitative and reflective skills, so that, they can re- enter their communities' job markets to contribute to the social and economic projects of the country.

Third, crucially, there is a need to provide refresher courses for members of the judiciary especially the newly appointed judges, spanning international and regional human treaties as well as other recognised courses of international obligations to which Ghana is a signatory. This would enable the judges, police officers and the government's lawyers, who work as the prosecutorial arm of the judiciary, to be mindful and respectful of prisoners' rights; thus, desisting from practices which constitute verballing and unfair trial. Furthermore, the Commission for Human Rights and Administrative Justice (CHRAJ), ${ }^{4}$ which is a government institution, established to promote the human rights of Ghanaians, should intensify its educational campaign activities to deepen the people's knowledge about their human rights and violations.

Fourth, prison should be a final resort. The government and judiciary must collaborate to adopt efficient community and probation programmes to help rehabilitate offenders, who engage in minor offences such as petty stealing, fighting, small debtors and minor family squabbles. Sam Lewis (2005: 127) argues that: "long sentences lead to overcrowding within the prison system which produce conditions of severe health implications". Therefore, Ghana needs to invest adequately in prison centers to implement effective medical and rehabilitation programmes to transform prisoners into competent labour force, for the country's socioeconomic development.

\section{Conclusion}

Prisoners' right to health care is protected under international law, regional human rights instrument as well as the 1992 Constitution of Ghana. Similarly, the Ghanaian Judiciary should be more activists in interpreting international human rights instruments, WHO principles, African Charter as well as domestic constitutional provisions to protect offenders against arbitrarily long-term jail sentences, for minor and trivial offences. Thus, the government is obliged to adopt and implement rehabilitative programmes, which would not only protect prisoners' wellbeing, but also seek to reform them to become participants of the socioeconomic prosperity of the country. However, those offenders whose crimes constitute security threat to the nation and are serving longer jail terms, retain their dignity as human beings, therefore, they must be treated respectably in accordance with international human rights and constitutional provisions. Lastly, the prison authorities, doctors, nurses, pharmacists and allied personnel, working within prison centers, have a duty to ensure that prisoners' health are protected, failing such responsibilities attract legal sanctions.

${ }^{1}$ Ahumah Ocansey v The Electoral Commission, Center for Human Rights and Civil Liberties (CHURCHIL v Attorney-General (2010) SCGLR 575

The facts of the above case were that: Mr Ahumah Ocansey, challenged the Government that, serving a prison term did not bar his human rights to exercise his voting franchise a Ghanaian. Delivering the judgment, Wood (Mrs) CJ, stated among other things, that “... However, there is no doubt that voting rights constitutes a fundamental right of such significance or importance; it does qualify as fundamental human rights. However, article 33 (5) is unquestionably a part of Chapter 5 of the Constitution. It cannot properly therefore be properly contended that other fundamental human rights, which are not expressly provided for in Chapter 5 are for that reason excluded by the framers of the Constitution. Finally, the right to vote is a political and a fundamental right at the same time. This is clearly borne by Article 25 of the International Covenant on Civil and Political Rights.

${ }^{2}$ Ibrahim Kwarteng Oppong's Report, see note 1.

${ }^{3}$ Ghana beyond Aid Strategic Document (April 2019): Among other things, the document states that, "a country where everyone has opportunities to develop to their fullest God-given potential - a Ghana where everyone has access to education, training and productive employment, good health in line with sustainable development goals (SDG)".

${ }^{4}$ The Commission for Human Rights and Administrative Justice (CHRAJ) established in 1993 by an Act of Parliament, Article 216: to ensure equity, fairness, accountability, and transparency in life, with a focus to promote human rights in Ghana. 
Reference:

Bernard, M. S. (1994). An eye for an eye: The status of international law on the humane treatment of Prisoners. 25 Rutgers Law journal, 25 (3), 759-798.

Bingham, T. (2010). The Rule of Law. London: The Penguin Books, p.53.

Evans, M and Murray, R. (2002). The special rapporteur in the African system, in Malcolm Evans and Rachel Murray (Eds), The African Charter on human and peoples' rights: The system in practice, 1986-2000, Cambridge: Cambridge University Press, 280.

Gubbay, R. A. (1997). The protection and enforcement of fundamental human rights: The Zimbabwe experience. Human Rights Quarterly, 19 (2), 227-254.

Harari, N. Y. (2018). 21 Lessons for the 21st Century. London: Jonathan Cape.

Kerwin, J. G. (1983). The role of United Nations General Assembly Resolutions in determining international law in United Nations Court. Duke Law Journal, 1983, 876-899.

Lewis, Sam. (2005). Rehabilitation: Headline or footnote in the new penal policy. Probation Journal, $52(2), 119-135$.

Lines, R. (2008). The Right to health of prisoners in international human rights law. International Journal of Prisoner Health, March 4(1) 3-53

Looschelders, D. and Olzen, D. (Seller, 2009). '842 BGB' in Julius Von Staudinger, Kommentaur Zum Burgerlichen Gesetzbuch 2, Paras 211, 82

Miller, D. N. (1995). International protection of the rights of Prisoners: Is solitary confinement in the United States a violation of international standards. California Western International Law Journal, 26, 139-172.

Mujuzi, D. J. (2006). An analysis of the approach to the right to freedom from torture adopted by the African Commission on human and Peoples' rights. African Human Rights Law Journal, 6(2), 423-441.

Oule, N. Y. and others (2019). The unique jurisdiction of the African Court on human and peoples' rights: Protection of human rights beyond the African Charter. Emory International Law Review, 33(2), 204-222.

Scriven, A. and Hodgins, M. (2012). Health Promoting Settings: Principles and Practice. London: Sages publications Ltd.

Simooya, O. O. (2010). Infection in prison in low and middle-income Countries: Prevalence and prevention strategies. The Open Infectious Diseases Journal, 4, 33-37.

Ssenyonjo, M. (2018). Responding to human rights violations in Africa: Assessing the role of the African Commission and court of human and peoples' rights. International Human Rights Law Review, 7, 1-42.

Shery, S. (2013). A Summary of why we need more of judicial activism, Vanderbilt Law school, 16 Green Bag, Micro Symposium, 2d 449.

Toman, J. (1984). Quasi-legal standards and guidelines for protecting human rights of detained persons, in Hurst Hannum (Ed), Guide to international human rights practice, 200-202.

Woodall, J., De Viggiani, N., Dixey, J., and South, J. (2014). Moving prison health along: towards an integrative framework for action to develop health promotion and tackle social determinants of health. Criminal Justice Studies, 27(1), $114-132$.

Martin, Craig. (2019). Challenging and refining the unwilling or unable doctrine. Vanderbilt Journal of International law, 52(2), 389459.

Gumede, V. (2016). Leadership for Africa's development: revisiting indigenous African leadership and setting the agenda for political leadership. Journal of Black Studies, 8(1), 79-90. 